\title{
PRINCIPAL COLLABORATIVE LEADERSHIP AND LEVEL OF JOB SATISFACTION AMONG PRIMARY SCHOOL TEACHERS
}

\author{
Nuramalina Zainal Abidin ${ }^{1}$, Bity Salwana Alias ${ }^{2}$ \\ National University of Malaysia \\ Email: amaalinazainal@gmail.com
}

\begin{abstract}
Headmaster collaborative leadership is important because this practice is able to contribute to the level of teachers' job satisfaction which is still an issue in the world of education to this day. This study was conducted to identify the collaborative leadership practices of headmasters and its relationship with to the level of teachers' job satisfaction in Kota Tinggi, Johor. This study is a survey using a quantitative approach. The respondents of the study consisted of 226 primary school teachers. Descriptive and inferential analysis using SPSS software was used to answer the research questions. The findings showed that the level of collaborative leadership of headmasters as a whole was at a very high level (mean $=4.45$, s.p. $=$ 0.71), while the level of job satisfaction of teachers was at a very high level (mean $=4.23$, s.p. $=0.71)$. Analysis through a Pearson Correlation test also showed that there was a significant and strong positive relationship between the collaborative leadership of Headmaster and the level of teachers' job satisfaction $(r=0.628, p<0.01)$. The implication is that the Ministry of Education (MOE) needs to review the conditions for the appointment of headmasters by improving the policy of the National Professional Qualification for Educational Leaders (NPQEL) to ensure that every leader is skilled in practicing collaborative leadership. In conclusion, collaborative leadership practiced by headmasters is seen as an ideal leadership style and able to increase the level of job satisfaction of teachers.
\end{abstract}

Keywords; collaborative leadership, effective leadership, job satisfaction, leadership practice.

\section{INTRODUCTION}

Globalization has resulted many changes in various sectors. The world of education is no exception. Changes in education are always happening to keep pace with today's global changes. This causes the world of education to become increasingly challenging, especially for education citizens. Therefore, educational institutions today need effective leadership to face the changing of education. Leaders determines the excellence of an educational institution (Roselena Mansor \& Mohd Izham Mohd Hamzah, 2015). Thus, the Ministry of Education will ensure that every school, regardless of location and performance level, will have a high-quality Headmaster and supportive the leadership team to provide instructional leadership and drive an overall school performance as included in the Malaysia Education Blueprint 2012-2025 (Kementerian Pendidikan Malaysia, 2013). School leaders nowadays play a collective and global role, no longer an individual one.

Leadership refers to management and administration to be more systematic and able to create comfort to subordinate employees. According to Tahir et al. (2018), the factor that plays an important role in creating a stable organization and ready to drive change is leadership. Thus, leadership means the quality of a department head in ensuring that the employees under his supervision are able to perform their duties well and at the same time be able to achieve work objectives with excellence.

Collaborative leadership was pioneered by Chrislip \& Larson (1994) where leadership is seen as a relationship in pursuit of common goals and mutual benefit to all who work together to achieve goals. Tan Kai Yee \& Aida Hanim A. Hamid (2018) stated four important aspects of collaborative leadership, namely clear responsibilities, involvement in decision making and knowledge sharing. According to Karnan \& Marimuthu (2021), the 
practice of collaborative leadership patterns causes leaders to implement organizational leadership more actively. Collaborative leadership encourages leaders and members of organizations to work together and share knowledge and experience. In addition, collaborative leadership also enhances social learning, and communication between members of the organization more effectively. Collaborative leaders must have clear goals and effective techniques, involve all parties either in making a decision or problem solving, have clear responsibilities, and be smart establishing interpersonal relationships.

Tan Kai Yee \& Aida Hanim A. Hamid (2018) The study of a democratic learning community exists under collaborative leadership through power sharing and cooperation between leaders and subordinates to achieve common goals. This leadership indirectly affects teachers' job satisfaction. Teachers are given the opportunity to develop their potential, abilities and skills in order to contribute to school excellence. All school staff are also given the same authority and responsibility in resolving any problems that arise or making certain decisions to ensure that the goals of the organization are achieved.

Collaborative leaders are able to guide members to be more open in sharing information and experiences, cultivate positive thinking, and establish effective two -way communication to achieve the set mission and vision (Karnan \& Marimuthu, 2021). Collaborative practices are important in school management. According to a study by Samriangjit et al. (2016) it was found that collaborative leadership style improves the effectiveness of primary school management in Thailand.

A study by Cleveland \& Cleveland (2018) is about research on collaborative leadership. Researchers have discussed how collaborative leadership is performed, the concept of collaboration and the process of building a community of engagement through collaboration. Researchers state the collaboration function has a positive effect on forming and maintaining a stable team. This will help team members understand each other's capabilities as well as foster cooperation.

A survey study using a quantitative approach on the collaborative leadership style of head teachers and self -efficacy of primary school teachers in Fenoj, Iran was conducted by Mehdinezhad \& Arbabi (2015) The results of a study involving a total of 196 respondents consisting of 82 female teachers and 114 male teachers found that there was a significant relationship between the collaborative leadership style of head teachers with teachers' self -efficacy $(r=0.248, p=.001)$. The trust -building dimension in the collaborative leadership style of head teachers was found to contribute the most to the improvement of teachers 'self -efficacy $(B=.379, p=0.002)$.

Tan Kai Yee \& Aida Hanim A. Hamid (2018) conducted a study to examine the relationship between the collaborative leadership of headmasters with the level of teacher commitment in SJKC, Batu Pahat district, Johor. A survey study using a quantitative approach involving 120 respondents made a correlation analysis and the results showed a strong and significant positive relationship between the level of collaborative leadership of principals and the level of teacher commitment to school $[r(118)=0.744, p<0.05]$.

Therefore, collaborative leadership is seen as an ideal leadership style and able to increase the level of job satisfaction of teachers and at the same time ensure school excellence is enhanced with the existence of quality and committed teachers in line with the 5th call in PPPM 2013-2025.

However, the study of Wee Seng Huat \& Mohammed Sani Ibrahim (2018) stated that school administration in Malaysia does not practice collaborative leadership style. Based on the data on the transfer application of primary school teachers in the district of Kota Tinggi (2020) shows 308 teachers who applied to change schools. Therefore, this problem raises interest for researchers to conduct a study to see the continuity between the collaborative leadership of headmasters with job satisfaction of primary school teachers in the district of Kota Tinggi. 
The results obtained, can identify the level of headmasters' collaborative leadership and job satisfaction of school teachers in Kota Tinggi. Next, this study will answer the question of whether the collaborative leadership of principals influences and contributes to teachers' job satisfaction factors in schools. Researchers also hope that this study can be an indicator of teachers 'perceptions of headmasters' leadership practices and its impact on teachers' job satisfaction with the quality of their work.

This study is also expected to help administrators to be more sensitive and find solutions on how their leadership patterns can affect teachers' job satisfaction in schools. Researchers also think that this study is important because it can be used as a guideline or a source of reference for administrators who are the backbone in school to improve the quality of their leadership and thus able to increase teacher job satisfaction. Thus, this study can be used as a reference guide to further enhance the effectiveness of the leadership of existing headmasters.

\section{METHOD}

The research design of this study used a quantitative approach. A questionnaire (Google Form) was distributed to 226 school teachers in the Kota Tinggi District, Johor. According to Babbie (2008), a quantitative research only involves number -related data in the process of analyzing the study data. The descriptive study used by the researcher acts as an explanation of the cause and effect based on the data and information that has been obtained.

The population for this study is a total of 553 teachers who serve in 14 primary schools in the District of Kota Tinggi, Johor. 226 teachers were selected as respondents to represent teachers in the Kota Tinggi District based on the sample size determination table by (Krejcie \& Morgan, 2016)

The sampling method used for this study is a random sampling method. According to Buyung \& Shafii (2017) sampling is a method of taking some data from a study population. This method is an appropriate research method in saving time and reducing the cost of researcher expenses. The selection of a random sample is a process of drawing from each layer of the population of teachers who serve in the District of Kota Tinggi and have the opportunity to be the study sample (respondents). Teachers will be randomly selected according to the turn number in the list of teachers in the school. Through this turn, number method will make it easier for researchers to select samples more fairly and effectively.

According to Idris Awang (2001) there are four methods of data collection that are often used by researchers in studies such as questionnaires, interviews, experimental and observation. However, the use of questionnaires as a measurement method of study is more effective and can help in reducing the cost of expenses, saving time and energy in the collection of findings (Soo Yew Phong, 2011).

In the process of data collection for this study, the researcher has provided a detailed description of the purpose and objectives of the study to provide an initial overview of the questionnaire that will be answered by the respondents. A description of the use of the five -point Likert scale and abbreviations are also given on the first page of the questionnaire to make it easier for respondents to choose the right scale. 
Received: 2021-12-17 Revised: 2022-01-07 Approved: 2021-01-13

\section{RESULT AND DISCUSSION}

1.1 Result

\subsubsection{Collaborative Leadership}

Table 1.Mean score and score interpretation for Collaborative Leadership

\begin{tabular}{llccl}
\hline No. & \multicolumn{1}{c}{$\begin{array}{c}\text { Collaborative Leadership } \\
\text { Practices }\end{array}$} & Mean & $\begin{array}{c}\text { Standard Deviation } \\
\text { (SD) }\end{array}$ & Level \\
\hline 1. & Effective leadership & 4.44 & 0.74 & Very high \\
2. & Clear goals & 4.45 & 0.71 & Very high \\
3. & Effective Communication & 4.43 & 0.78 & Very high \\
4. & Involvement in decision making & 4.41 & 0.69 & Very high \\
5. & Clear responsibilities & 4.49 & 0.76 & Very high \\
& Collaborative leadership practice & 4.45 & 0.71 & Very high
\end{tabular}

Table 1 shows the results of the descriptive analysis consists of the mean value, standard deviation along with the interpretation level of collaborative leadership practice. Overall, the level of collaborative leadership practice was at a very high level with an average score value $($ mean $=4.45$, s.d. $=0.71)$. Based on table 1 , among the five dimensions, the clear responsibility dimension had the highest mean value (mean $=4.49$, $\mathrm{sd}=0.76$ ), followed by the clear goal dimension (mean $=4.45$, s.d. $=0.71$ ) and the dimension effective leadership (mean $=4.44$, s.d. $=0.74$ ). For the dimension of effective communication, the mean value obtained is at a very high level (mean $=4.43$, s.d. $=0.78$ ). The dimension of involvement in decision making is the dimension that obtained the lowest mean value among the five dimensions studied with a score $($ mean $=4.4$, s.d. $=0.69)$, but is still at a very high level. These findings indicate that headmasters in Kota Tinggi have a clear responsibility and practice more than others.

\subsubsection{Job Satisfaction}

This section has 5 dimensions as shown below.

Table 1. Mean score and satisfaction level

\begin{tabular}{lccc}
\hline Item & Mean & $\begin{array}{c}\text { Standard Deviation } \\
\text { (SD) }\end{array}$ & Level
\end{tabular}

(SD)

\begin{tabular}{|c|c|c|c|}
\hline 1. Work performance & 4,34 & 0.76 & Very high \\
\hline 2. Salary & 4.08 & 0.92 & Very high \\
\hline 3. Interpersonal relationship & 4.36 & 0.66 & Very high \\
\hline 4. Job achievement & 4.16 & 0.90 & Very high \\
\hline 5. Working condition & 4.19 & 0.78 & Very high \\
\hline Teachers' job satisfaction & 4.24 & 0.71 & Very high \\
\hline
\end{tabular}

Based on the data shown in table 1 shows the findings of the descriptive analysis of the level of job satisfaction of teachers. Between the five dimensions studied are at a very high level. The interpersonal relationship dimension got the highest mean score (mean = 4.36 , s.d. $=0.66$ ). For the work performance dimension, it showed the average mean score obtained $($ mean $=4.34$, s.d. $=0.76$ ). While for the work condition dimension, it recorded an average mean score (average mean score $=4.19$, s.d. $=0.78$ ). The job achievement dimension shows $($ mean $=4.16$, s.d. $=0.90)$. The salary dimension is the dimension that recorded a lower average mean score than the other dimensions with an average mean score $($ mean $=4.09$, s.d. $=0.92$ ) but still at a very high level. Overall, the level of job 
satisfaction of teachers is at a very high level with an average score value (mean $=4.24$, s.d. $=0.71$.

\subsection{Discussion}

\subsubsection{Teachers Evaluation on Principal's Collaborative Leadership Practices}

To answer the first research question which is identifying the level of collaborative leadership of headmasters in Kota Tinggi, Johor,twenty questions were designed by the researcher and submitted to the respondents. The study resulted that the overall mean of the respondents was at a very high level. Overall, respondents showed the highest rating on the clear responsibility practice dimension 4.49 which was demonstrated by the head teacher and followed by a clear goal dimension 4.45. While the dimension of involvement in decision making practice achieved the lowest mean score of 4.19 and less practiced compared to other collaborative practices.

This finding is in line with the study of Tan Kai Yee \& Aida Hanim A. Hamid (2018) on the relationship between collaborative leadership of headmasters with the level of teacher commitment in SJKC Bandar zone, Batu Pahat district, Johor. It shows important practices that need to be implemented by SJKC collaborative leaders is a clear responsibility and goals. This suggests that clear responsibilities and goals are important dimensions of collaborative leadership practice to ensure that the collaborative leadership of principals is at a high level. Brown (2011) states that excellent schools have a clear mission and vision. Chrislip \& Larson (1994) also state that collaborative leaders need to inspire action and commitment. Leaders need to know the responsibilities and goals clearly in order to begin a process that will unite subordinates by convincing them to work together in resolving an issue. In conclusion, school administrators who practice collaborative leadership need to have clear responsibilities and goals in administering schools.

Next, the dimensions of effective leadership and communication recorded an average mean score of 4.44, 4.43 and were at a very high level. This indicates that teachers in Kota Tinggi are satisfied with the communication practices implemented by school principals. Effective communication practices also have an impact on effective leadership. According to Ishak et al (2012), principals with communication and diplomacy skills can gain the support of teachers and at the same time encourage the involvement of parents and the local community in efforts to improve the quality of school education. In addition, Johansson and Hamrin, (2014) also stated the importance of communication in the task of coordination, change management and initiatives to improve the performance of an organization. In this regard, effective communication will create a good relationship between headmasters and teachers and at the same time be able to influence teachers to accept the changes that occur in education.

The involvement in decision making is a dimension of the collaborative practice of headmasters which recorded the lowest mean score of 4.41 compared to other practices. This shows that headmasters in Kota Tinggi District take their own decisions and less involve teachers in the decision-making process. This finding is in line with the study of Tan Kai Yee \& Aida Hanim A. Hamid (2018) where the dimension of involvement in decision making is a collaborative practice of head teachers who recorded the lowest mean value and less practiced.

\subsubsection{Teachers' job satisfaction}

The second research question is to identify the level of job satisfaction of primary school teachers in Kota Tinggi, Johor. A total of twenty -five question items were designed and prepared involving aspects of job performance, job achievement, salary, interpersonal relationships and working conditions that were prepared. Overall, the level of teachers' job satisfaction of teachers is very high with a mean value of 4.24. These findings are in line with the study of Karnan \& Marimuthu, (2021); Tor Xin Yuan \& Bity Salwana (2021); 
Wee Seng Huat \& Mohammed Sani Ibrahim,(2018). The high level of teachers' job satisfaction of teachers can influence teachers to work better to improve productivity, quality of teaching and learning. Indirectly it can improve school performance as well as create a culture of quality and dedicated educators.

The study showed that the mean of the interpersonal relationship aspect obtained the highest mean value with a mean value of 4.36 . Salary aspect was the lowest aspect with a mean value of 4.08. Overall, interpersonal relationships will affect teachers 'job satisfaction if not met. The results of this study are in line with a previous study conducted by Tor Xin Yuan \& Bity Salwana (2021) where relationships with peers are important for teachers in achieving job satisfaction. Teachers stated that they were satisfied with the attitude, encouragement and efficiency of their colleagues in performing their duties at school. This aspect of interpersonal relationships also does not only assess teachers 'job satisfaction with colleagues, it also includes teachers' satisfaction with the treatment and attitude of head teachers. The teachers also expressed their satisfaction with the behavior of the headmaster who was concerned about the progress of the teachers and gave appreciation for their excellent work.

1.2.3 The relationship between the collaborative leadership of head teachers and its relationship with job satisfaction of primary school teachers in Kota Tinggi District, Johor.

Table 1. The relationship between the collaborative leadership of head teachers and job satisfaction of primary school teachers in Kota Tinggi District, Johor.

\begin{tabular}{lc}
\hline & $\begin{array}{c}\text { Teachers' Job Satisfaction } \\
(\mathrm{r})\end{array}$ \\
\hline Collaborative Leadership Practices & $.628^{* *}$ \\
\hline${ }^{* *}$ Significance at the 0.01 level. &
\end{tabular}

Overall, the results of data analysis show that there is a positive and significant relationship between the collaborative leadership practices of headmasters and its relationship with job satisfaction of primary school teachers in Kota Tinggi, Johor. Based on the findings of the data obtained, the level of collaborative leadership of head teachers has a strong relationship $(r=628, p<0.01)$ and significant $(p=0.000<.005)$ with the level of job satisfaction of teachers. This relationship has positive and significant value. This proves that the collaborative leadership practices of headmasters are increasingly being practiced in school management, so the probability for teachers to get job satisfaction on their work is very strong.

\subsection{Implication for Policy}

Ministry of Education (MOE) needs to review the conditions of the appointment of headmasters by improving the policy of the National Professional Qualification for Educational Leaders (NPQEL) to ensure that every leader is skilled in practicing collaborative leadership. These skills are important in producing ideal leadership and able to increase the level of teachers' job satisfaction and at the same time can improve school performance and create a culture of quality and dedicated educators in line with the 5th call in the Malaysian Education Development Plan (2013-2025) emphasizes the importance of ensuring high performance leadership placed in each school

\subsection{Implication for Practice}

To increase the types of leadership and management training at the Aminudin Baki Institute to further enhance the capacity of school leaders in Malaysia. The IAB can implement the Guidance Assistance Program to provide training in stages starting from 
JPN, PPD and school leaders. In addition, such as Global School Leader program can also be implemented to share and combine the knowledge and skills of international and domestic experts in providing training to administrators.

\section{CONCLUSION}

In conclusion, this study shows that the collaborative leadership of headmasters and the level of job satisfaction of primary school teachers in Kota Tinggi, Johor are at a very high level. In addition, this study proves that leadership practice plays an important role in teachers' job satisfaction. Leaders who practice collaborative leadership such as having clear goals and responsibilities will succeed in increasing teachers 'job satisfaction levels and school performance. This gives a clear picture that Next, the creation of good interpersonal relationships between colleagues as well as the headmaster among the school population will be able to create factors that stimulate job satisfaction of teachers. Furthermore, the researcher hopes that this study can be used as a guide and reference to the Ministry of Education Malaysia (MOE), State Education Department (JPN) and District Education Office (PPD) in strengthening the education policy formulated in terms of collaborative leadership practices. Overall, the principal's collaborative leadership practice is seen as an ideal leadership style and able to increase the level of job satisfaction of teachers.

Studies on affective leadership can be conducted to measure the effectiveness of other leadership practices and how headmaster can implement some leadership practices in their administration so that the welfare and level of teachers' job satisfaction can be enhanced. In addition, the findings of this study can also be improved by involving more respondents and expanding selected study locations. This study can be conducted at the state or national level so that stakeholders such as the MOE get a clear picture of the level of job satisfaction of existing teachers. This is important so that improvements can be designed and MOE can re-evaluate the policies that have been implemented. Finally, further recommendations on collaborative leadership practices among middle -class leaders and their effectiveness in improving teacher job satisfaction can be undertaken. This is because leadership in schools is not just focused on the headmaster or principal only. Senior assistant teachers and committee heads also play a role in driving the school towards excellence

\section{BIBLIOGRAFI}

Awang, I. (2001). Kaedah penyelidikan suatu sorotan.

Babbie, E. (2008). The Basics of Socal Research.

Brown, Y. S. (2011). Parish Leadership: A Shared Responsibility-A Model of Collaborative Parish Leadership Formation, Engaging Ordained and Lay Ecclesiastical Ministers in the Los Angeles Archdiocese [Catholic University of America].

https://cuislandora.wrlc.org/islandora/object/etd\%3A131/datastream/PDF/vi ew

Buyung, M. R., \& Shafii, H. (2017). PEMBINAAN KOLEJ KEDIAMAN LESTARI: KESELESAAN PENGHUNI MENGIKUT JANTINA TERHADAP KEMUDAHAN BILIK PENGINAPAN KOLEJ KEDIAMAN DI UNIVERSITI AWAM. Journal of Techno-Social, 
Received: 2021-12-17 Revised: 2022-01-07 Approved: 2021-01-13

9(2). https://publisher.uthm.edu.my/ojs/index.php/JTS/article/view/2210

Chrislip, D., \& Larson, C. E. (1994). Collaborative Leadership: How Citizens and Civic Leaders Can Make a Difference. Undefined.

Cleveland, M., \& Cleveland, S. (2018). Building Engaged Communities-A Collaborative Leadership Approach. Smart Cities. 1(1), 155-162. https://doi.org/10.3390/SMARTCITIES1010009

Huat, W. S. \& M. S. I. (2018). Kepimpinan Kolaboratif Guru Besar dan Hubungannya dengan Kepuasan Kerja Guru. PROCEEDINGS OF THE INTERNATIONAL CONFERENCE OF FUTURE EDUCATION AND ADVANCES 2018. https://www.masree.info/conference-info/icofea18_proceeding-2018/

Ishak, R., Faizal, M., \& Ghani Abstrak, A. (2012). Amalan Kepimpinan Terbaik untuk Sekolah "Organisasi Pembelajaran" (Best Leadership Practices for “Learning Organization” Schools). Jurnal Pendidikan Malaysia, 37(2), 35-41.

Johansson, C., \& Hamrin, S. (2014). Conceptualizing communicative leadership: A framework for analysing and developing leaders' communication competence. Corporate Communications An International Journal. https://doi.org/10.1108/CCIJ-02-2013-0007

Karnan, K., \& Marimuthu, K. (2021). GAYA KEPIMPINAN KOLABORATIF PENGETUA DAN TAHAP KEPUASAN KERJA GURU SEKOLAH MENENGAH KEBANGSAAN [PRINCIPAL COLLABORATIVE LEADERSHIP STYLE AND LEVEL OF JOB SATISFACTION OF NATIONAL SECONDARY SCHOOL TEACHERS]. Muallim Journal of Social Science and Humanities, 191-207. https://doi.org/10.33306/mjssh/133

Pelan Pembangunan Pendidikan 2013-2025, (2013).

https://www.moe.gov.my/index.php/dasarmenu/pelan-pembangunanpendidikan-2013-2025

Krejcie, R. v., \& Morgan, D. W. (2016). Determining Sample Size for Research Activities. 30(3), 607-610. http://dx.doi.org/10.1177/001316447003000308

Mansor, R. \& M. I. M. H. (2015). Kepimpinan berkualiti: perspektif mengenai kompetensi yang diperlukan untuk memimpin dengan berkesan. http://ejournals.ukm.my/pengurusan/issue/view/749

Mehdinezhad, V., \& Arbabi, A. (2015). School principals' collaborative leadership style and relation it to teachers' self-efficacy. International Journal of Research Studies in Education, 4(5). https: / /doi.org/10.5861/IJRSE.2015.1218 SPhong, oo Y. (2011). Bab 3: Metodologi Kajian: Soal Selidik. http://studentsrepo.um.edu.my/3391/6/Bab3.pdf 
Received: 2021-12-17 Revised: 2022-01-07 Approved: 2021-01-13

Tahir, Aziz, Ahmad Zamri Mansor, \& G. D. (2018). Amalan Kepimpinan Transformasional Guru Besar dan Hubungannya Terhadap Kepuasan Kerja Guru Sekolah Daerah Miri.

Yee, T. K. \& A. H. A. H. (2018). Kepimpinan Kolaboratif Guru Besar dan Hubungannya dengan Komitmen Guru Terhadap Sekolah. PROCEEDINGS OF THE INTERNATIONAL CONFERENCE OF FUTURE EDUCATION AND ADVANCES 2018. http://www.masree.info/conference-info/icofea18_proceeding-2018/

Yuan, T. X. \& B. S. (2021). Kepimpinan Transformasi Guru Besar Dan Kepuasan Kerja Guru Di SJKC Daerah Hulu Perak. https://myjms.mohe.gov.my/index.php/jdpd/article/view/12563/6284

\section{COPYRIGHT}

Copyright (c) 2021 Nuramalina Zainal Abidin, Bity Salwana Alias

c) (i) (8) This work is licensed under a Creative Commons AttributionNonCommercial 4.0 International License. 